\title{
河川放流した養殖アマゴ成熟親魚の 産卵床立地条件と卵の発眼率
}

\author{
德原哲也, * 岸大㸝, 原徹, 熊崎 博
}

(2009 年 10 月 19 日受付, 2010 年 1 月 28 日受理)

岐阜県河川環境研究所下呂支所

Egg eyeing rates and physical characteristics of spawning redds of stocked amago salmon Oncorhynchus masou ishikawae in a stream

\section{Tetsuya TOKUHARA,* DAIsuke KISHI, TORU HARA AND HIROSHI KUMAZAKI}

\begin{abstract}
Gero Branch, Gifu Prefectural Research Institute for Freshwater Fish and Aquatic Environments, Gero, Gifu
\end{abstract} 509-2592, Japan

We released mature male and female amago salmon Oncorhynchus masou ishikawae reared in a hatchery into a small stream in central Japan and surveyed the location of spawning sites, water depth, current velocity, substrate size and the egg eyeing rates in the redds in 2007.

The redds were observed only at the pool ends and in riffles. The average water depth was $20.5 \pm 9.0 \mathrm{~cm}$ $($ Mean \pm SD) . Averages of surface and bottom velocity were $22.7 \pm 9.1 \mathrm{~cm} / \mathrm{sec}$ and $16.1 \pm 10.7 \mathrm{~cm} / \mathrm{sec}$, respectively. Preferred substrate size was fine pebbles of $16-32 \mathrm{~mm}$. The average egg eyeing rate in the redds was calculated to be $90.6 \%$. As a result, physical characteristics of redds and egg eyeing rates observed in our study were similar to the values of wild fish reported in previous studies.

キーワード：Oncorhynchus masou ishikawae，アマゴ，放流，親魚，産卵，産卵床，発眼率

我が国の代表的な溪流魚であるイワナSalvelinus leucomaenis, ヤマメOncorhynchus masou masou, アマ ゴ O. m. ishikawae の増殖方法のひとつである発眼卵放 流は, 今までの研究の中で良好なふ化率を得られない結 果が少なからず報告されており,1)これは卵の育成に不 適な場所を選定したためであると考えられている。放 流場所の選定は放流従事者の経験や能力に大きく左右さ れる。発眼卵放流のマニュアルが作成, 配布されてい る3,4) とはいえ, 専業者が減り, 高齢化が進んでいると 考えられる内水面漁業協同組合の現状に抢いて, 場所選 定の個人差の解消や埋設技量の向上を図ることは困難で ある。

我々は, 放流従事者による発眼卵の埋設作業の代替策 として, 産卵期に十分に成熟した魚を河川に放流し, こ の放流個体に自発的に産卵させる増殖手法（以下, 親魚 放流と記述）の可能性に注目した。そこで本研究では, 成熟したアマゴ養殖魚を実際に河川に放流し産卵させ， 形成された産卵床の立地条件と産着卵の発眼率を調查す
ることで親魚放流の有用性を検討した。

\section{試料および方法}

調査河川 木兽川水系飛騨川支流竹原川に抢いて調査 を実施した（Fig. 1)。この河川は岐阜・長野県境の三 国山を水源とする流路長 $12.5 \mathrm{~km}$ の小河川である。調 査区間は中流部の堰堤間の流程 $590 \mathrm{~m}$ の区間の水域 (平均水面幅約 $9 \mathrm{~m}$, 河床勾配 2.28\%) である (Fig. 1)。 調查区間下限の堰堤の落差は $1 \mathrm{~m}$ と高くないものの, 水吒き部はコンクリートで被覆され水深が浅いため, 増 水時以外に魚の遡上は不可能であると考えられた。 2007 年 10 月 5 日に調查区間に打いて潜水観察を行 い，区間内に産卵可能な成熟雌親魚がいないことを確認 した。この区間では上流から流下してきたと考えられる アマゴ野生魚が春季に生息しているほか, アマゴの稚魚 放流, 成魚放流が行われている。それにも関わらず, 成 熟をで生き残った大型魚がいなかった理由として, 遊漁 者が多く釣獲圧が高いことと, 調査区間はアユの漁場で

* Tel : 81-576-52-3111(407). Fax : 81-576-52-4354. Email : tokuhara-tetsuya@pref.gifu.lg.jp 


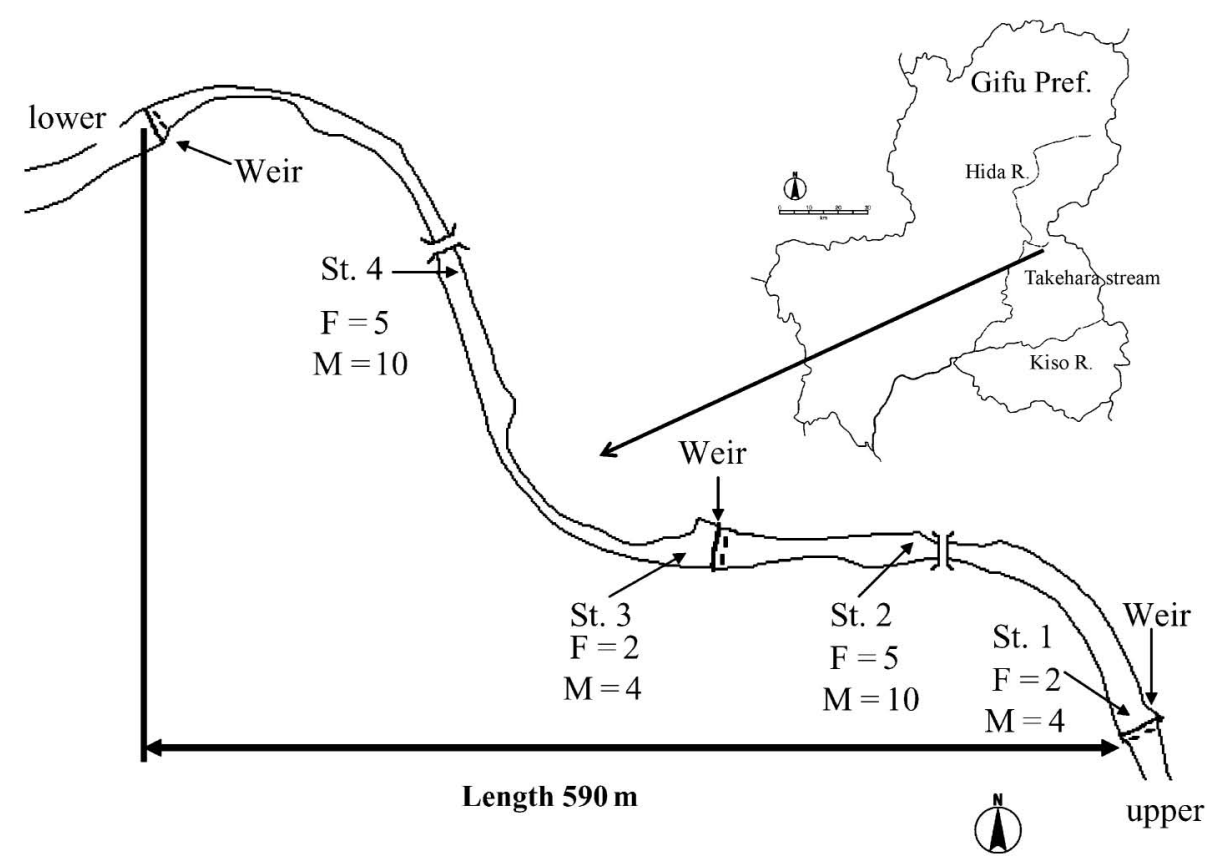

Fig. 1 Map of the study area in the Takehara Stream in the Kiso River system. St.1-4 show the release sites. F, M show the number of female and male amago salmon released at each station, respectively.

もあるため夏季に行われる網漁で混獲されたことが考え られた。

供試魚 岐阜県河川環境研究所下呂支所において飼育 されているアマゴの $1+$ 歳魚を放流に使用した。これら は 1966 年および 1967 年に木曽川水系飛騨川およびそ の支流で採捕された天然魚を初代親魚とし, 5,6) 以降，人 工受精で継代飼育されてきた系統の魚である。

調査方法 2007 年の 10 月 15 日午後 4 時に調查区間 内の 4 力所の淵に雌親魚 14 尾（平均尾叉長 $34.3 \pm 1.2$ $\mathrm{cm}$ （土は標準偏差。以下同様）平均体重 $556.6 \pm 72.2$ $\mathrm{g}$ ), 雄親魚 28 尾 (平均尾叉長 $25.0 \pm 3.4 \mathrm{~cm}$ 平均体重 $186.3 \pm 76.8 \mathrm{~g} ）$ を放流した。このとき，大きめの淵 2 ヶ所にはそれぞれ雌親魚 5 個体, 雄親魚 10 個体, 小さ い淵 2 ヶ所にはそれぞれ雌親魚 2 個体, 雄親魚 4 個体 と, 1:2 の雌雄比で個体数を配分して放流した（Fig. 1)。な抢，放流個体は夏期の池中飼育時に多数のチョ ウモドキArgulus coregoni に寄生され，背部抢よび体側 部に多くの虫食い斑が形成されていた。本研究では, そ の虫食い斑を放流個体の標識とした。

放流の翌日から, 午前 8 時頃から 30 分間を目処に毎 日 1 回, 調查区間内を巡視して放流親魚のペアリング 抢よび産卵床の有無の調査を行った。産卵床が見つかっ た場合，黄色のペンキで塗装したこぶし大の石をその場 所に置いてマーク（目印）とした。調査は放流魚が確認 できなくなるまで行った。

アマゴの卵が外部からの物理的衝撃に対する耐性を獲 得する発眼期（積算温度 $250 \sim 300^{\circ} \mathrm{C}$ ) 7 ) を迎えた 11 月 6
〜14 日に, マークを付けた産卵床について, 河床形態 を淵, 瀬, 淵尻（淵から瀬への移行帯）の 3 区分で記 録し, 産卵床の長径, 短径, 水深, 流速を測定した。水 深については親魚が産卵後, 卵を産むための窪みを掘っ た時に掘り出された磎が山状に盛り上がった箇所（テー ルスピル tail spill）の前方部を計測し， $1 \mathrm{~cm}$ 単位で記 録した。流速については, 水深を測定した場所の表層 （水面下約 $2 \mathrm{~cm}$ ） と底層（底面加約 $5 \mathrm{~cm}$ ）を流速計 （株式会社ケネック製電磁流速計 VE10）で計測し，0.1 $\mathrm{cm} / \mathrm{sec}$ 単位で記録した。これらの測定後, 産卵床を鋤 策で掘り起こして産着卵の有無を確認した。卵が確認さ れた場合は手網やホースポンプ8)を使って卵を回収し， 発眼率 $(100 \times$ 発眼卵/回収した卵の総数）を記録した。 確認した卵のうち, 死卵を除去して, 発眼卵の久を速や かに砂碩に埋設し直した後, 産卵床 1 床当たり約 $2 \mathrm{~kg}$ を目処に砂碩を採集し持ち帰った。持ち帰った砂碩を風 乾した後, 粒径 (D) D $<2 \mathrm{~mm}, 2 \mathrm{~mm} \leqq \mathrm{D}<4 \mathrm{~mm}, 4$ $\mathrm{mm} \leqq \mathrm{D}<8 \mathrm{~mm}, 8 \mathrm{~mm} \leqq \mathrm{D}<16 \mathrm{~mm}, 16 \mathrm{~mm} \leqq \mathrm{D}<32$ $\mathrm{mm}, 32 \mathrm{~mm} \leqq \mathrm{D}<64 \mathrm{~mm}, 64 \mathrm{~mm} \leqq \mathrm{D}$ の 7 段階に分けて 重量組成を求めた。

\section{結果}

放流翌日の 10 月 16 日からペアリングが確認され た。その後, 放流親魚は 10 月 26 日を最後に確認でき なくなったため, 10 月 28 日に巡視を終了した。

産卵床はSt. 1 で 2 床, St. 2 で 5 床, St. 3 で 1 床, St. 4 で 8 床の計 16 床発見された。それらのうち 14 床 

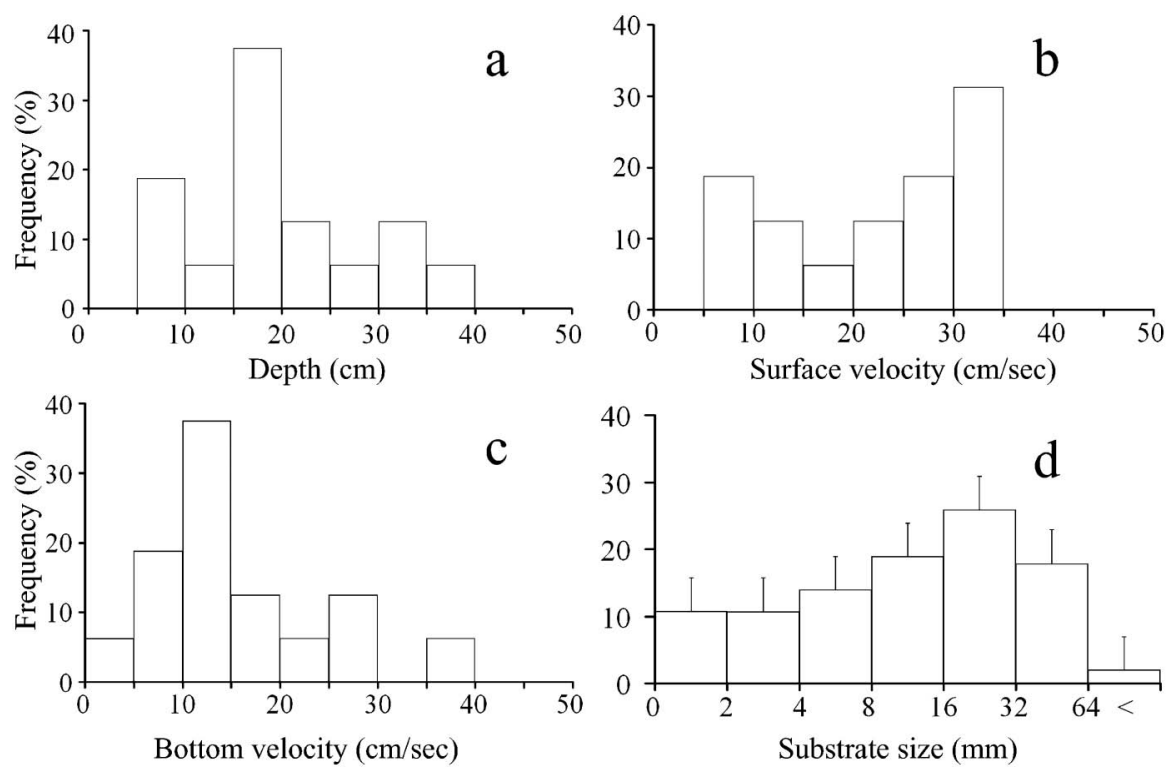

Fig. 2 Histogram of (a) water depth, (b) surface water velocity, (c) bottom water velocity, and (d) substrate size of spawning redds of the amago salmon. Vertical lines in the substrate size histogram show the standard deviations.

(90.9\%) が淵から瀬へ移行する駆けあがり部（淵尻）

に，2 床が瀬にそれぞれ形成されていた。産卵床の長径 の平均は $65.6 \pm 14.1 \mathrm{~cm}$, 範囲は $40 \sim 100 \mathrm{~cm}$ であり, 短径の平均は $39.4 \pm 6.8 \mathrm{~cm}$, 範囲は $30 \sim 50 \mathrm{~cm}$ であっ た。産卵床が形成された場所の水深は平均 $20.5 \pm 9.0$ $\mathrm{cm}$ ，範囲 7〜 $37 \mathrm{~cm}$ であった (Fig. 2a)。産卵床の表層 流速は平均 $22.7 \pm 9.1 \mathrm{~cm} / \mathrm{sec}$, 範囲 $8.5 \sim 33.0 \mathrm{~cm} / \mathrm{sec}$ (Fig. $2 \mathrm{~b}$ ), 底層流速は平均 $16.1 \pm 10.7 \mathrm{~cm} / \mathrm{sec}$, 範囲 $4.2 \sim 39.0 \mathrm{~cm} / \mathrm{sec}$ であった (Fig. 2c)。産卵床を構成す る底質の割合は， $16 \mathrm{~mm} \leqq \mathrm{D}<32 \mathrm{~mm}$ ( $\mathrm{D}$ は粒径) のも のが $25.9 \%, 8 \mathrm{~mm} \leqq \mathrm{D}<16 \mathrm{~mm}$ のものが $18.9 \%, 32$ $\mathrm{mm} \leqq \mathrm{D}<64 \mathrm{~mm}$ のものが $17.9 \%$ の順で多く, これら で全体の $62.7 \%$ を占めていた（Fig. 2d）。

16 床の産卵床のうち, 卵室が礫の深い位置に形成さ れ，すべての卵を回収できなかった 1 床を除く 15 床の 総卵数は 4381 粒, 平均は $292.1 \pm 181.0$ 粒, 範囲 $27 \sim$ 767 粒であり, 発眼率を求めたところ, 平均 $90.6 \pm 7.2$ \%, 範囲 74.1 97.2\% であった。

\section{考察}

本研究によって得られた結果をアマゴやヤマメ, イワ ナの自然個体群の既往の知見と比較する。産卵場所につ いては, イワナは淵尻や瀬, 淵脇や淵・瀬の岸辺の物陰 で産卵するのに対して，ヤマメは淵尻と瀬を選んで産卵 する。9,10) 本研究でも放流されたアマゴ親魚は淵尻と瀬 で産卵していた。

産卵床の大きさは, 既往のアマゴのもの（長径 : 平均 $52.6 \mathrm{~cm}$, 範囲 33 $100 \mathrm{~cm}$; 短径: 平均 $34.1 \mathrm{~cm}$, 範囲 20〜60 cm）とほぼ同じであった。 ${ }^{11)}$ 産卵床の水深につ
いては, 既往のアマゴのものでは平均 $22.4 \mathrm{~cm}$, 範囲 $10 \sim 30 \mathrm{~cm}$, ヤマメでは平均 $22.3 \mathrm{~cm}$, 範囲 $10 \sim 42 \mathrm{~cm}$ であり, 9,11) 今回のアマゴ放流親魚の数值はこれらとほ ぼ同じであった。産卵床の流速についても, 表層流速は ヤマメ産卵床の表層流速の平均 $28.6 \pm 14.1 \mathrm{~cm} / \mathrm{sec}$, 範 囲 7.1 57.9 cm/sec に近かった。9) アマゴについては, 平均 $13.9 \mathrm{~cm} / \mathrm{sec}$ という水深不明の流速の数值があ り,11)これは今回のアマゴ放流親魚の底層流速に近かっ た。

産卵床の底質についても既往のアマゴのもの（容積比 で 10 20 mm の小砂利の割合が最も高い) やヤマメの もの（8～16 mm, 16〜32 mm で主に構成）に近かっ た。9,11)

自然個体群の卵の発眼率については, イワナでは平均 $60.1 \%$, 範囲 0 95\%, ヤマメでは平均 $55.1 \%$, 範囲 0 〜 $100 \%$ という報告がある。12,13) アマゴでは卵の発生入 テージが不明であるが, 生残率の平均は $94.7 \%$, 範囲 は 44.4 100\%であった。(白石ら ${ }^{11)}$ の表に記載されて いた数值を元に著者らが計算）今回のアマゴ放流親魚の 発眼率は平均で $90 \%$ を超え, 範囲も $74.1 \sim 97.2 \%$ であ り, 既往の知見に比べて, 総じて良好であると考えられ る。

現在, 溪流魚の放流方法には, 稚魚放流, 成魚放流, 発眼卵放流があり, 14,15) これらはいずれも, 継代飼育さ れた養殖魚やその卵が使用されている。本研究の対象で ある親魚放流も, 養殖魚の使用が前提となる。イワナ, ヤマメ，アマゴ養殖魚は人間の手で卵と精子を搾取さ れ, 人工授精により再生産されており,16) 産卵行動を経 験していない。自然条件下では適正な産卵行動ができな 
い個体の適応度は低く，本来は淘汰されるものと考えら れる。しかし，養殖条件下では，こうした適応度の低い 個体が継代されている可能性がある。そして，そのよう な養殖魚が適正な産卵行動を行うかどうかの検証はアマ ゴについてはなされていなかった。しかしながら, 今回 のデータから，アマゴ放流親魚はアマゴやヤマメの自然 個体群々ほぼ同一条件の場所で産卵し, その発眼率も良 好であったことから, 継代された養殖魚であっても産卵 行動が可能であると考えられる。

これまで, 発眼卵放流と稚魚放流は放流後成長させて から，成魚放流は放流後即座に利用するという違いがあ るものの，いずれも放流した個体そのものを資源として 利用するものである。今回の親魚放流は放流した個体で はなく，その次世代の増殖効果を狙う点で他の放流方法 と異なる。親魚放流は発眼卵放流々同様に, 自然の産卵 場がある河川であれば実施することが可能であり，その メリットは次のと拈りであると考えられる。すなわち, (1)養殖池での高密度飼育による鰖の矮小化や欠損, いわ ゆる「スレ」を受けないので稚魚放流や成魚放流に比べ 容姿の良い魚を増やすことできる，(2)放流時期である産 卵期は禁漁期なので漁獲による減耗がない，(3)放流手法 が成魚放流と同じであるため，成魚放流を行っている漁 業協同組合であれば特別な技術習得，用具購入の必要が ない，(4)発眼卵放流では河川の砂䃋底への 1 力所 500 1000 粒程度の卵の埋設 4 を放流場所毎に繰り返す必要 があるのに対して, 親魚放流では産卵可能と思われる場 所に魚を放流するのみであるため, 発眼卵放流より作業 量が少なくてすむ，(5)放流された魚が自発的に産卵する ため，発眼卵放流に比べて放流従事者の放流場所選定ミ スや埋設ミスを回避できる。一方でデメリットとして, (1)産卵適地の無い川には放流しても効果が望めない。(2) 輸送には活魚トラックが必要となり，車を保有していな い漁業協同組合にとってはコストがかかる。(3)同じく輸 送にトラックが必要なため, 川沿いに車道のない川に放 流するのが難しい。(4)雌放流魚が産卵前に減耗すると著 しく増殖効率が低下寸る, が挙げられる。

近年, 溪流魚の在来個体群の保全意識が高まってい る。17) 在来個体群の保全のためには, 交雑による遺伝的 攪乱を回避するため，その生息域で種苗放流はできな い。18) 渓流魚を漁業権魚種として免許されている漁業協 同組合は在来個体群の保全と遊漁の両方を考元る必要が あり，そのような状況でその両方を成立させる方法とし て溪流漁場の「ゾーニング管理」が注目されている。18) これは, 在来個体群の保全と, 増殖義務の履行および遊 漁による資源利用の併存のため, 漁場を在来個体群の保 全区域々, 遊漁・漁業の利用区域に分けて管理するとい う考え方である。18) 親魚放流は, 成魚放流々同様に, 渓 流に隣接する車道の存在や活魚水槽付きトラックによる
輸送が前提となる方法であり, 集落に比較的近い渓流が その主要な対象地になるものと考えられる。こうした里 地の渓流は, これまでの放流事業によって, 既に在来個 体と放流個体との交雑が進行した場所であり,ゾーニン グ管理における利用区域に該当することが多いと考えら れる。一方, 残存する在来個体群の分布域は, 車による アクセスが困難で, 放流事業の実施が容易でない源流域 に存在することが多い。17,19)こうした源流域は, 車で容 易に近づけないため, 親魚放流の対象地として不適であ る。すなわち, 親魚放流が在来個体群に対して遺伝的攪 乱を引き起こす機会は少ないものと考えられる。ただ し, 放流の対象地を選定する際には, 在来個体群の分布 域すなわち保全区域においては, 親魚放流を実施しない という認識や取り決めが必要であり, 本放流方法は利用 区域での一増殖手段としてそのメリットとデメリットを 考えた上で他の放流方法と組久合わせて計画的に適用さ れるべきものである。な抢, 里地の溪流は, 流域開発や 河川改修によって産卵適地が減少している場合が少なく ないと予測されることから，必要に応じて人工産卵場の 造成3,18,20)を併用することが効果的と考えられる。

また, この人工産卵場との併用は, 教育分野に貢献で きると考えられる。現在, サケ科魚類を題材とした環境 教育のプログラムが実践され, ${ }^{21-24)}$ 国内外でサケ科魚類 の産卵行動を観察する生物教育プログラムが実施されて いる。21,25) 親魚放流と人工産卵場の併用は, 天然魚が減 少してしまった河川に㧈いてもサケ科魚類を使った環境 教育が可能と考えられる。例えば, 学校の総合学習にお いて，ヤマメやアマゴといった渓流のサケ科魚類の産卵 行動に注目する場合, 時間配分や引率の際の制約上，そ の候補地として里地の溪流が適していると考えられる。 そこで, 漁業協同組合による親魚放流の実施に合わせて 観察適地に人工産卵場を造成することで, 子供達により 安全かつ確実に産卵行動を観察してもらうという力法が 考えられる。このように親魚放流は, 増殖事業と並行し て教育分野での活用も期待され, 水産資源の増殖事業に ついての啓発活動を行う上でも新たな題材になりうるも のと考えられる。

親魚放流はアユPlecoglossus altivelis altivelis での実施 例があるが, 26) 本研究以外に産着卵の生残を実際に追跡 調查した例はない。今後は増殖効果の検証や放流技術の 高度化を進めるとともに, 他の放流方法との費用対効果 の検証が必要である。

\section{謝辞}

本研究を行うにあたり, 益田川漁業協同組合の皆様, 特に桂川善彦組合長と桂川 豊参事, 熊崎純三支部長に は調査に対して様々な便宜を図っていただいた。また， 中央水産研究所の中村智幸博士には文章の校閲をしてい 
ただき, 岐阜県農政部水産課の武藤 義範氏にはいろい

ろとご助言をいただいた。ここに深謝の意を表します。

\section{文献}

1）石田力三. 総括.「マス類の河川放流に関する研究- I III」全国湖沼河川養殖研究会マス類放流部会. 1985; 127.

2） 中村智幸，土居隆秀. 溪流に打けるイワナ発眼卵放流由 来群の生残, 成長, 密度打よび現存量. 日水誌 2009; 75: 198-203.

3）水産庁, 水産総合研究センター中央水産研究所.「溪流魚 の人工産卵場のつくり方〈付録〉溪流魚の発眼卵放流の 方法（パンフレット）」(中村智幸編）水産庁. 2008.

4）武居 薰. 発眼卵放流の方法. 「守る・増やす溪流魚」 (中村智幸・飯田 遙編著), 農山漁村文化協会, 東京. 2009; 66-71.

5）立川 瓦，本荘鉄夫．アマゴの増殖に関する研究 天然 河川産アマゴの池中養成と採卵について。岐水試研報 1966; 13: 7-18.

6）立川 瓦, 本荘鉄夫, 田口錠次, 熊崎隆夫. アマゴの飼 育について。㞳水試研報 1967; 14: 3-47.

7）桑田知宣, 德原哲也. アマゴ.「水産増養殖システム 2 淡 水魚」(隆島史夫・村井 衛編) 恒星社厚生閣, 東京. $2005 ; 57-67$.

8）岸 大弼, 苅谷哲治, 德原哲也. 産卵床からのホースポ ンプによる発眼卵採集. 水産技術 2008; 1: 25-28.

9）中村智幸. 鬼怒川上流におけるイワナ, ヤマメの産卵床 の立地条件の比較. 日水誌 1999; 65: 427-433.

10）中村智幸. 渓流に生きる知恵一イワナとヤマメの共存機 構一.「魚類環境生態学入門」(猿渡敏郎編著) 東海大学 出版会, 秦野. 2006; 2-22.

11）白石芳一, 鈴木喜三郎, 玉田五郎. 三重県馬野川のアマ ゴに関する水産生物学的研究一第二報 産卵習性に関す 万研究一. 淡水区水産研究所研究資料 1958; 18: 1-19.

12）中村智幸. 人工産卵場に抢けるイワナの産卵之産着卵の 交化. 日水誌 1999; 65: 434-440.

13) Kondou T, Takeshita N, Nakazono A, Kimura S. Egg sur- vival in a fluvial population of Masu salmon, in relation to intragravel conditions in spawning redds. Trans. Am. Fish. Soc. 2001; 130: 969-974.

14）水産総合研究センター叢書.「守る・増やす渓流魚」（中 村智幸・飯田 遙編著), 農山漁村文化協会, 東京. 2009.

15）全国内水面漁業共同組合連合会.「イワナ, ヤマメ, アマ ゴの増殖と管理」, 東京. 2004 .

16）隆島史夫・村井 衛編.「水産増養殖システム 2 淡水魚」, 恒星社厚生閣, 東京. 2005 .

17）中村智幸. 聞き取り調査によるイワナ在来個体群の生息 分布推定. 砂防学会誌 $2001 ; \mathbf{5 3}, 3-9$.

18）中村智幸.「イワナをもっと増やしたい!」フライの雑誌 社, 東京. 2006.

19）德原哲也, 藤井亮吏, 苅谷哲治, 桑田知宣. 長良川にお けるアマゴ在来個体群の分布状況. 岐阜河環研報 1967; 52: 23-26.

20）中村智幸・土井隆秀. 造成方法.「守る・増やす渓流魚」 (中村智幸・飯田 遙編著), 農山漁村文化協会, 東京. 2009; 78-82.

21）奥山 洌, 高嶋幸男, 小宮山英重. 実践報告 北海道東 部, 標津町・清里町および斜里町における「サケ学習」 の実践. 環境教育研究 $2003 ; \mathbf{6}: 127-138$.

22）齋藤里奈, 高嶋幸男, 小宮山英重. 北海道東部, 標津町 におけるサケ学習プログラムの開発 (III) 一学生はサケ体 験学習の体験をどう受けとめたか一. へき地教育研究 2003; 57: 51-78.

23）野呂幸生, 高嶋幸男, 小宮山英重. 実践報告 北海道東 部, 標津町薫別小中学校に抢ける「サケ学習」プログラ ムの教育実践一地域の環境・人を生かして一. 環境教育 研究 2004; 7: 49-64.

24）棟方有宗, 三浦 剛. サクラマスのライフサイクルの調 節機構の解明と教材化. 宮城教育大学紀要 2008; 43: 105-112.

25) Schmetterling DA, Bernd-Cohen T. Native species conservation through education. Fisheries 2002; 27: 10-15.

26）高橋勇夫, 東 健作.「ここまでわかったアユの本」. 築 地書館, 東京. 2006 . 